\title{
Does ISIS satisfy the criteria of an apocalyptic Islamic cult? An evidence- based historical qualitative meta-analysis
}

\section{by Bruce A. Barron and Diane L. Maye}

\section{(cc) $\mathrm{BY}$}

This work is licensed under a Creative Commons Attribution 3.0 License.

\begin{abstract}
The U.S. has been battling ISIS and its forerunners for over two decades; however, ISIS continues to endure and expand. While described as a death cult by some political leaders and other key stakeholders, this assertion received little consideration in the scholarly literature. The purpose of this study was to ascertain whether ISIS satisfied the criteria of an apocalyptic Islamic cult through the application of a historical qualitative research design and meta-analysis. Based on the results, the null hypothesis that ISIS does not satisfy the criteria of an apocalyptic Islamic cult was rejected, and the hypothesis that ISIS satisfies the criteria of an apocalyptic Islamic cult was accepted. This outcome has significant implications regarding U.S. policy and how practitioners develop effective strategies to neutralize the threat.
\end{abstract}

Keywords: ISIS; Islam; typology; sect; cult; apocalyptic

\section{Introduction}

he Islamic State of Iraq and al-Sham (ISIS or ISIL) is recognized as one of the most violent terrorist organizations in the world. Their persistence is well demonstrated by the fact the United States (U.S.) has been combatting ISIS and its forerunners for over two decades. ISIS continues to expand its influence despite the allocation of increasing counterterrorism resources. For example, the U.S. reportedly spent more than $\$ 5.53$ billion in the fight against ISIS and currently spends almost $\$ 11$ million per day (U.S. Department of Defense, 2015).

The reasons for ISIS' continued success despite the vast amount of resources invested by the U.S. are uncertain. Regardless of this lack of understanding, U.S. military strategy to dismantle ISIS recently changed from a hybrid model to a conventional boots-on-the-ground model (Durden, 2016; Tilghman, 2016). The current strategy is based on the assumption that ISIS is first and foremost a terrorist organization.

Although ISIS employs terrorist tactics, some political leaders and other key stakeholders characterize ISIS as a death cult (ABC News, 2015; World News, 2015). However, the cult-like aspects of ISIS receive little consideration in the scholarly literature. The significance of identifying and countering an apocalyptic cult should not be underestimated. For example, several post mortem analyses of the U.S. federal assault on the Branch Davidian compound in Waco, Texas concluded the tragedy was directly related to the misinformed application of aggressive tactics that were misinterpreted by the cult leader as the beginning of the apocalypse (Pitts, 1998, p. 209).

Considering the lessons learned from the Waco tragedy and unsuccessful efforts to degrade and dismantle ISIS, it is important to determine ISIS' status as an apocalyptic Islamic cult versus a religious terrorist organization or other entity. Identifying ISIS as a cult has important strategic security implications 


\section{Journal of Terrorism Research}

regarding the development of effective counter measures in defeating this organization while concomitantly minimizing costs in terms of lives and resources. Therefore, the purpose of this research is to ascertain whether ISIS satisfies the criteria of an apocalyptic Islamic cult.

\section{Literature Review}

The continued expansion of ISIS presents significant challenges to U.S. national security. Expectedly, strategies and tactics are based on the assumption ISIS is a brutal terrorist organization; however, this approach in neutralizing the threat is achieving marginal results. The idea ISIS might be an apocalyptic Islamic cult and its implications in thwarting their expansion led to a comprehensive search of scholarly and quasi-scholarly literature. The outcomes of the literature search are stratified across two domains; namely, research that concludes ISIS is a religious group and research that concludes ISIS is something other than religious group. The literature search did not include ISIS as a terrorist organization because this group is already a recognized terrorist group.

The literature review within the first domain is organized using the typological continuum influenced by Niebuhr (1929), Troeltsch (1931), Weber (1964), and Nelson (1968).

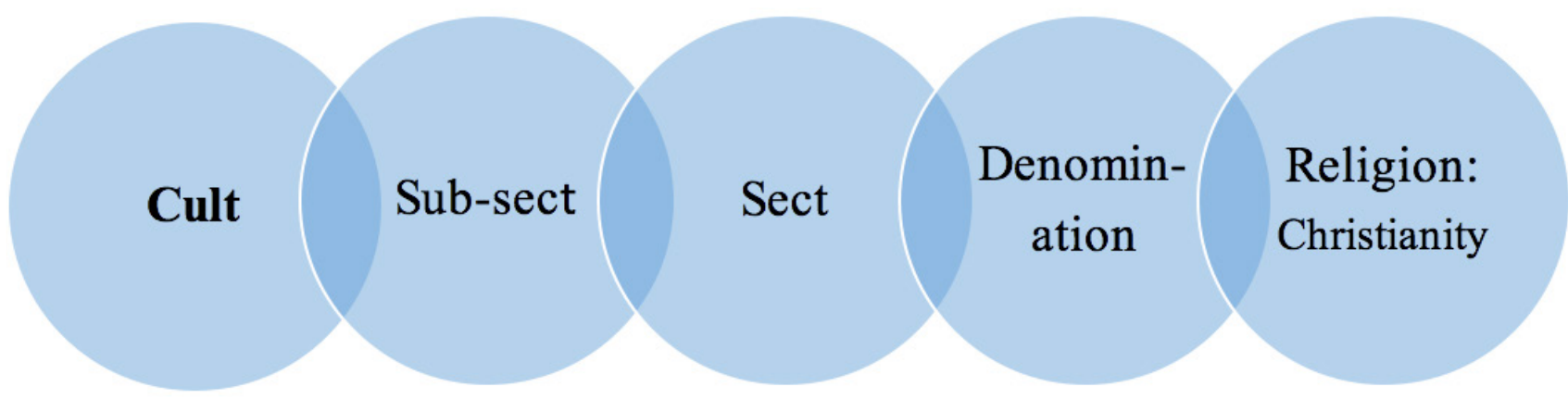

Figure 1: Christian-based typological continuum from cult to religion

It is important to realize this continuum is Christian-based and the boundaries between cults, sects, and religions are frequently blurred. The literature supporting ISIS as a religious entity is presented in order from left to right (i.e. cult - sect - religion).

A comprehensive literature search yielded three articles supporting the hypothesis that ISIS is cult (Berger, 2015; LaPalm, 2014; Schmid, 2015). Of these three sources, only LaPalm (2014, p. 7) concluded ISIS is a cult, stating "while many Islamist extremist organizations have cult-like features, ISIL is perhaps the most cultish in history." LaPalm uses Lifton's (1961) criteria as a basis for her analysis. She asserts ISIS satisfies all of Lifton's criteria except for that of confession. This research has several limitations: (1) thresholds for satisfying Lifton's criteria are not delineated, (2) the number of criteria required to satisfy Lifton's criteria is not specified, and (3) the paper is published in a non-refereed journal. As such, LaPalm's research is considered theoretical and hypothesis generating. Conversely, Berger's publication is considered both credible and reliable; however, this paper focuses on ISIS' use of social media rather than their religious ideology. Nevertheless, he proffers a definition for the word apocalyptic that is applied in this study. Lastly, Schmid's 


\section{Journal of Terrorism Research}

research does not assess ISIS as a cult; rather, he provides counter arguments to ISIS' propaganda suggesting their ideology is cult-like as compared to modern Islam.

Sliding slightly to the right on the continuum, Barker (2014, p. 10) implies ISIS is a sub-sect because of their extreme Salafi-Jihadist ideology. Similarly, Souaiaia's (2015) historical review of the genealogy of ISIS provides great insight regarding their religious beliefs. He argues through an analysis of Islamic Traditionalism that ISIS is an Islamic legal denomination, which is comparable to that of a Christian sub-sect. Lastly, Fromson and Simon (2015) characterize ISIS as both a sect and cult; terms that are not clearly defined in their paper.

The second domain of the literature review consists of research concluding ISIS is neither a religion-based group nor a terrorist organization. In addition to being a cult and sect, Fromson and Simon (2015, p. 8) argue ISIS is also a guerilla army and territorial administrator. Other publications assert ISIS is a hybrid terrorist organization (Ganor, 2015), revolutionary armed group (Kalyvas, 2015), revolutionary state (Walt, 2015), and pseudo-state (Cronin, 2015). While these studies fail to support the hypothesis that ISIS is an apocalyptic cult, it is clear there is no consensus regarding the true nature of ISIS.

In summary the literature search identified one quasi-scholarly paper (LaPalm, 2014). LaPalm studied ISIS' cult-like attributes and concluded ISIS was a cult; however, her research was regarded as theoretical, not scientific. Other published research has characterized ISIS as an entity ranging from a cult to a pseudo-state as summarized in Table 1.

\begin{tabular}{|c|c|}
\hline Religion-based organization & Not a religion-based organization \\
\hline Sect & Pseudo-state \\
\hline Sub-sect & Revolutionary state \\
\hline Cult & Revolutionary armed group \\
\hline & Guerilla army \\
\hline & Hybrid terrorist organization \\
\hline
\end{tabular}

Table 1: Characterization of ISIS

There was no consensus in the academic literature regarding the true essence of ISIS. According to Sun Tzu (trans. 2000), "[i]f you know the enemy and know yourself, you need not fear the result of a hundred battles." In this situation, it appears policy officials as well as scholars and academics do not understand the true essence of ISIS, which may be contributing to their inability to neutralize this threat. Therefore, the outcome of the literature review substantiated the necessity for this research.

\section{Methodology}

This research used an evidence-based historical qualitative research design combined with a meta-analysis of unclassified literature. The search strategy included key words and phrases followed by the use of Boolean operators to narrow search results. The meta-analysis involved the systematic collection of information from the following sources: (1) library sources, (2) commercial online services, (3) gray literature, (4) Internet sources, (5) searchable databases, (6) social media, and (7) subject matter experts. Information assessed as credible and reliable were entered into a Microsoft Word document while valid sources were entered into the Microsoft Word Reference Manager. 


\section{Journal of Terrorism Research}

The hypothesis and null hypothesis for the study are:

$$
\begin{aligned}
& \mathrm{H}_{1} \text { : ISIS satisfies the criteria of an apocalyptic Islamic cult. } \\
& \mathrm{H}_{0} \text { : ISIS does not satisfy the criteria of an apocalyptic Islamic cult. }
\end{aligned}
$$

The research started with defining the word cult and identifying a valid list of cult characteristics. The term apocalyptic was also defined. Pertinent information regarding the actions of ISIS was collected and analyzed.

Due to the study design, structured analytic techniques (Heuer \& Pherson, 2011; Jones, 1998) were used to analyze the data. Key references for important differentiators were annotated. A comparative analysis was used to assess the degree of concordance across Islam (religion), Sunni Islam (sect), Salafist movement (movement), and ISIS ideology to approximate ISIS' location on the Islamic typological continuum depicted in Figure 2 (Barron, 2016, p. 20).

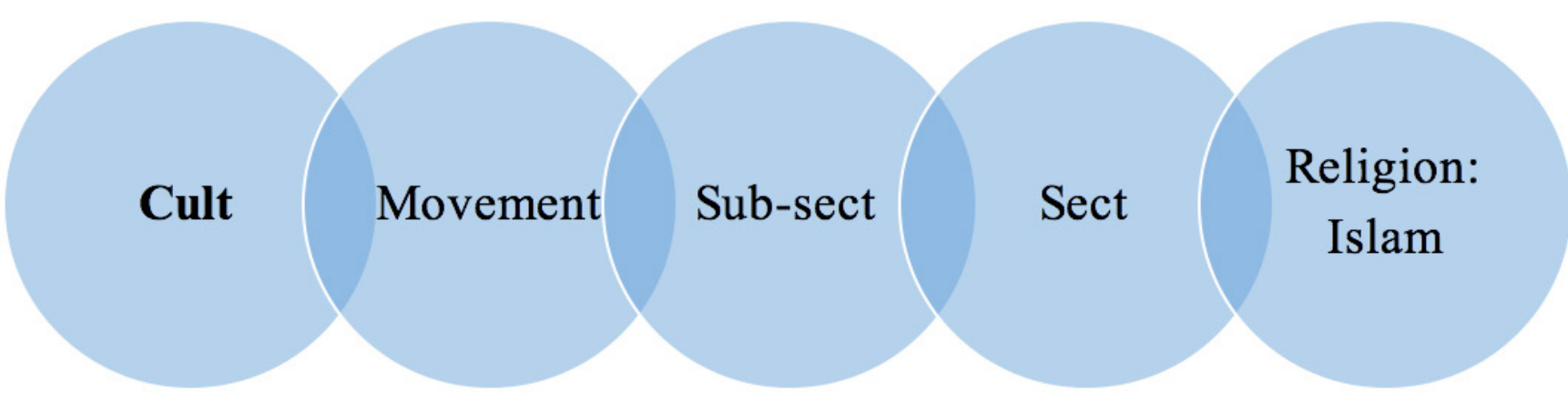

Figure 2: Islamic-based typological continuum from cult to religion

The second analysis applied Lifton's (1961) criteria to test the hypothesis. There were two reasons to use Lifton's criteria: (1) Lifton's publication is both credible and reliable, and (2) LaPalm (2014) applied Lifton's criteria to argue ISIS is a cult. Lastly, an Analysis of Competing Hypotheses (ACH) was performed to systematically evaluate alternative hypotheses and reduce the risk of researcher bias. The hypotheses tested included the following:

H1: ISIS is not a religion-based organization

H2: ISIS is a cult.

H3: ISIS is a movement.

H4: ISIS is a sub-sect

H5: ISIS is a sect.

H6: ISIS is an accepted religion.

The basic hypothesis (H2) was tested using three different analytic methods. The outcomes of the analyses were used to generate a probabilistic conclusion. It was required ISIS meet the definition of a cult and all three analyses must support the hypothesis to conclude with any reasonable degree of certainty that ISIS is a cult. Additionally, ISIS must also satisfy the definitions of apocalyptic and Islamic.

\section{Analysis}

The analysis begins with characterizing key terms such as religion, sect, movement, and cult. The word religion is "reserved for solutions to questions of ultimate meaning which postulate the existence of a 


\section{Journal of Terrorism Research}

supernatural being, world, or force, and which further postulate that this force is active, that events and conditions here on earth are influenced by the supernatural" (Stark \& Bainbridge, 1979, p. 119). The supernatural aspect of religion differentiates it from other organizations such as governments and terrorists organizations. Furthermore, established religions accept and are accepted by the dominant society (Stark \& Bainbridge, 1979, p. 123).

Whereas a sect is created by a split within an established religion, a religious movement attempts to cause or prevent change in a religion while striving to become the dominant faith (Stark \& Bainbridge, 1979; p. 124). Conversely, cults are groups that split from mainstream society espousing very different worldviews. Cults add "to that culture a new revelation or insight justifying the claim that it is different, new, more advanced" (Stark \& Bainbridge, 1979, p. 125).

Based on religious and sociological descriptions of cults, the working definition of cult for this study is: " $A$ cult is a group of people whose religious beliefs represent a radical split from other mainstream religions and sects. The organization's ideology and practices places them at odds with and creates tension in their dominant society. Its members usually display excessive devotion to the leader or ideology, and the leader or ideology is unquestioningly followed by its believers" (Barron, 2016, p. 26). A synthesis of the scholarly literature identified 10 key traits that characterize cults (Table 2).

\begin{tabular}{|c|l|l|}
\hline Cult characteristic & References \\
\hline 1. $\quad$ Charismatic leader & Alami, 2015; American Family Foundation, \\
& 2002; Cult Information Centre, 2016; Dawson, \\
& 2006, p. 28; Giambalvo, 2016; John, 2015; \\
& Lalich \& Langone, 2015; Langone, 2015; Tinaz, \\
& 2005, p. 88; Yinger, 1970 \\
\hline 2. Authoritarian leadership & Alami, 2015; American Family Foundation, \\
& 2002; Dawson, 2006, p. 28; Giambalvo, 2008; \\
& John, 2015; Lalich \& Langone, 2015; Langone, \\
& 2015; Richardson, 1993; Rhodes, 2011; Tinaz, \\
& 2005 \\
\hline 3. $\quad$ Exclusivism & American Family Foundation, 2002; Dawson, \\
& & 2006; Giambalvo, 2008; John, 2015; Lalich \& \\
& Langone, 2015; Langone, 2015; Rhodes, 2001; \\
& Stark \& Bainbridge, 1985; Wilson, 1982 \\
\hline $4 . \quad$ Nonconformists & Dawson, 2006; Giambalvo, 2008; John, 2015; \\
& Lalich \& Langone, 2015; Langone, 2015; \\
& Yinger, 1970 \\
\hline 5. Totalistic organization & American Family Foundation, 2002; Cult \\
& & Information Centre, 2016; Lifton, 1961; \\
& & Richardson, 1993; Stark \& Bainbridge, 1985; \\
& Tinaz, 2005 \\
\hline &
\end{tabular}




\section{Journal of Terrorism Research}

\begin{tabular}{|c|l|l|}
\hline 6. Systematic indoctrination & $\begin{array}{l}\text { Cult Information Centre, 2016; John, 2015; } \\
\text { Lalich \& Langone, 2015; Langone, 2015; } \\
\text { Rhodes, 2001; Richardson, 1993; Stark \& } \\
\text { Bainbridge, 1985 }\end{array}$ \\
\hline 7. $\quad$ Us-versus-them mindset & $\begin{array}{l}\text { American Family Foundation, 2002; Lalich } \\
\text { \& Langone, 2015; Langone, 2015; Stark \& } \\
\text { Bainbridge, 1985 }\end{array}$ \\
\hline 8. The ends justify the means & $\begin{array}{l}\text { American Family Foundation, 2002; Cult } \\
\text { Information Centre, 2016; Lalich \& Langone, } \\
\text { 2015; Langone, 2015 }\end{array}$ \\
\hline 9. $\quad$ Aggressive proselytizing & $\begin{array}{l}\text { American Family Foundation, 2002; Lalich \& } \\
\text { Langone, 2015; Langone, 2015; Richardson, } \\
\text { 1993; Stark \& Bainbridge, 1995 }\end{array}$ \\
\hline 10. $\quad$ Money driven & $\begin{array}{l}\text { American Family Foundation, 2002; John, } \\
\text { 2015; Lalich \& Langone, 2015; Langone, 2015 }\end{array}$ \\
\hline
\end{tabular}

Table 2: Cult characteristics

The typological comparative analysis is designed to ascertain ISIS' relative position on the Islamic-based continuum shown in Figure 2. In particular ISIS ideology is compared to Islam (religion), Sunni Islam (sect), and Salafist movement (movement). These entities are studied because ISIS' theology is based on SalafiJihadism, which links ISIS ideology with Islam (i.e. Salafi-Jihadism - Salafi Islam - Hanbali Islam - Sunni Islam - Islam). The characteristics used to differentiate these religious entities are a product of previously unpublished research (Barron, 2015, p. 15). The outcome of the comparative analysis is summarized in Table 3.

\begin{tabular}{|l|l|l|l|l|}
\hline Characteristics & Islam & Sunni Islam & $\begin{array}{l}\text { Salafist } \\
\text { movement }\end{array}$ & ISIS theology \\
\hline $\begin{array}{l}\text { Apocalyptic } \\
\text { beliefs, strong }\end{array}$ & No & No & No & $\begin{array}{l}\text { Yes } \\
\text { (Berger, 2015; Festinger, } \\
\text { Fromson \& Simon, 2015; } \\
\text { Inbari, 2015; McCants, } \\
2015 ; \text { Schmid, 2015; } \\
\text { Socolovsky \& Winston, } \\
2015 \text { Wood, 2015) }\end{array}$ \\
\hline $\begin{array}{l}\text { Beliefs / ideology, } \\
\text { conventional }\end{array}$ & Yes & Yes & $\begin{array}{l}\text { No } \\
\text { (Barker, 2014; Bunzel, } \\
2015 ; \text { Schmid, 2015: } \\
\text { Wood, 2015) }\end{array}$ \\
\hline $\begin{array}{l}\text { Born into } \\
\text { religion }\end{array}$ & Yes & Yes / No & No \\
\hline
\end{tabular}




\section{Journal of Terrorism Research}

\begin{tabular}{|c|c|c|c|c|}
\hline $\begin{array}{l}\text { Culturally } \\
\text { accepted }\end{array}$ & Yes & Yes & Yes / No & No \\
\hline Exalted status & No & No & Yes & $\begin{array}{l}\text { Yes } \\
\text { (Essam, 2014; Lister, 2015; } \\
\text { Schmid, 2015) }\end{array}$ \\
\hline Islamic based & Yes & Yes & Yes & $\begin{array}{l}\text { Yes } \\
\text { (Barker, 2014; Eckman, } \\
\text { 2015; Schmid, 2015: } \\
\text { Wood, 2015) }\end{array}$ \\
\hline $\begin{array}{l}\text { Living leader } \\
\text { centric }\end{array}$ & No & No & No & $\begin{array}{l}\text { Yes } \\
\text { (Chulov, 2014; Edwards, } \\
\text { 2015: Speckhard \& Yayla, } \\
\text { 2015) }\end{array}$ \\
\hline $\begin{array}{l}\text { Lifestyle fosters } \\
\text { isolationism }\end{array}$ & No & No & Yes & $\begin{array}{l}\text { Yes } \\
\text { (Alami, 2015; Shubert, } \\
\text { Haddad, \& Jones, 2016; } \\
\text { Peresin, 2015; Speckhard } \\
\text { \& Yayla, 2015; Walli, } \\
\text { 2015) }\end{array}$ \\
\hline $\begin{array}{l}\text { Membership } \\
\text { exclusive }\end{array}$ & No & No & Yes & $\begin{array}{l}\text { Yes } \\
\text { (Masi, 2014; Speckhard \& } \\
\text { Yayla, 2015; Walli, 2015) }\end{array}$ \\
\hline $\begin{array}{l}\text { Membership } \\
\text { inclusive }\end{array}$ & Yes & Yes & No & No \\
\hline $\begin{array}{l}\text { Preoccupied } \\
\text { with expanding } \\
\text { membership }\end{array}$ & Yes / No & Yes / No & Yes / No & $\begin{array}{l}\text { Yes } \\
\text { (Bean, 2016; Herrmann, } \\
\text { 2014; Lewis, 2015; } \\
\text { Peresin, 2015; Schmid, } \\
\text { 2015; Speckhard \& Yayla, } \\
\text { 2015; Walli, 2015) }\end{array}$ \\
\hline $\begin{array}{l}\text { Preoccupied with } \\
\text { making money }\end{array}$ & No & No & No & $\begin{array}{l}\text { Yes } \\
\text { (Alsodani, 2015; Cronin, } \\
\text { 2015; Speckhard \& Yayla, } \\
\text { 2015) }\end{array}$ \\
\hline Salvation, direct & No & No & Yes & $\begin{array}{l}\text { Yes } \\
\text { (Speckhard \& Yayla, 2015; } \\
\text { Walli, 2015) }\end{array}$ \\
\hline
\end{tabular}




\section{Journal of Terrorism Research}

\begin{tabular}{|l|l|l|l|l|}
\hline $\begin{array}{l}\text { Symbolism } \\
\text { extensive }\end{array}$ & No & No & No & $\begin{array}{l}\text { Yes } \\
\text { (Inbari, 2015; McCants, } \\
\text { 2015; Walli, 2015; West } \\
\text { Point, 2007) }\end{array}$ \\
\hline $\begin{array}{l}\text { Theology } \\
\text { dogmatic }\end{array}$ & Yes & Yes & Yes & Yes \\
\hline $\begin{array}{l}\text { Theology } \\
\text { ritualistic }\end{array}$ & Yes & Yes & Yes & Yes \\
\hline
\end{tabular}

Table 3: Comparison of ISIS to Islam (religion), Sunni Islam (sect), and Salafist movement (movement)

The results of the comparative analysis suggest ISIS is situated before Salafist movement on the Islamic continuum (Figure 3).

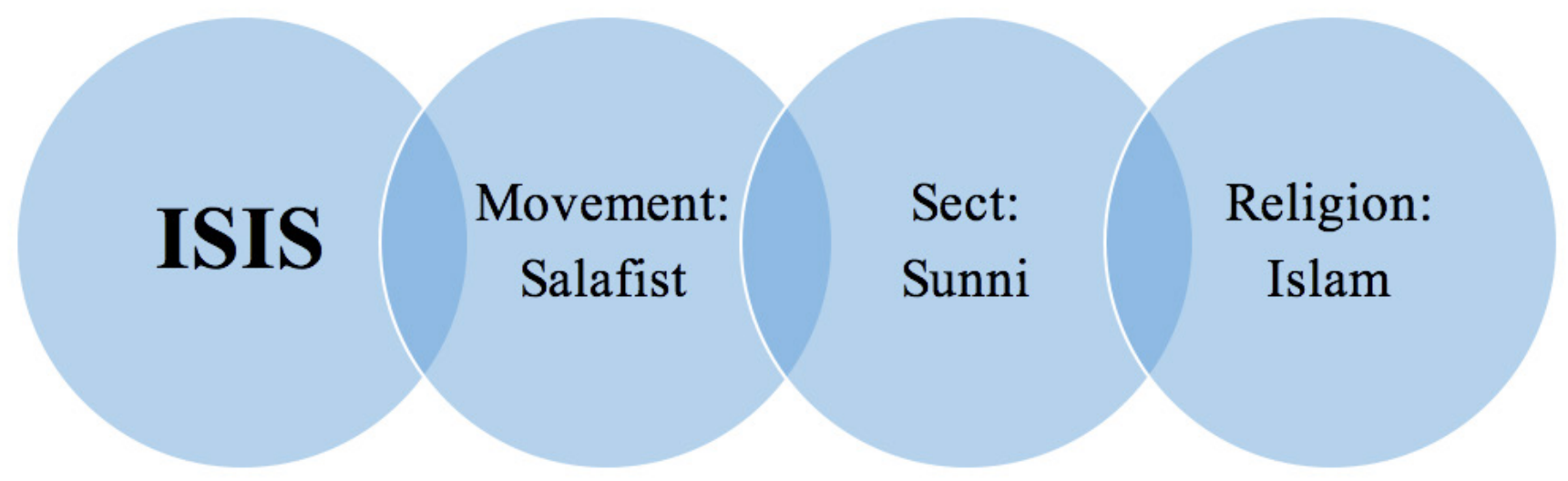

Figure 3: The relative location of ISIS on the continuum from cult to religion (Barron, 2016, p. 71)

The next analysis applies Lifton's criteria for totalism. According to Lifton (1961, p. 419), "[a]ny set of emotionally-charged convictions about man and his relationship to the natural or supernatural world - may be carried by its adherents in a totalistic direction. But this is most likely to occur with those ideologies which are most sweeping in their content and most ambitious - or messianic - in their claims, whether religious, political, or scientific. And where totalism exists, a religion, a political movement, or even a scientific organization becomes little more than a cult." Along these lines Lifton identified eight criteria common to totalistic organizations; however, not all criteria must be satisfied to classify a totalistic group as a cult (Lifton, 1961, p. 420). The results of this analysis are summarized in Table 4.

\begin{tabular}{|c|c|l|}
\hline Lifton criteria & ISIS methods & References \\
\hline Milieu control & Criterion satisfied & Alami, 2015; Al Arabiya, 2014; \\
& & LaPalm, 2014; Peresin, 2015; \\
& & Speckhard \& Yayla, 2015; \\
& & Wood, 2015; Zech \& Kelly, \\
& & 2015 \\
\hline
\end{tabular}




\section{Journal of Terrorism Research}

\begin{tabular}{|c|l|l|}
\hline Mystical manipulation & Criterion satisfied & $\begin{array}{l}\text { Berger, 2015; Fromson \& } \\
\text { Simon, 2015; Inbari, 2015; } \\
\text { LaPalm, 2014; McCants, 2015; } \\
\text { Schmid, 2015; Socolovsky \& } \\
\text { Winston, 2015; Wood, 2015 }\end{array}$ \\
\hline Demand for purity & Criterion satisfied & $\begin{array}{l}\text { Bunzel, 2015; Deikman, 2003; } \\
\text { LaPalm, 2014; McCants, 2015; } \\
\text { Speckhard \& Yayla, 2015 }\end{array}$ \\
\hline Cult of confession & Criterion not satisfied & LaPalm, 2014 \\
\hline Sacred science & Criterion satisfied & $\begin{array}{l}\text { Bunzel, 2015; LaPalm, 2014; } \\
\text { McCants, 2015; Wood, 2015 }\end{array}$ \\
\hline Loaded language & Criterion satisfied & $\begin{array}{l}\text { Bunzel, 2015; LaPalm, 2014; } \\
\text { McCants, 2015; Wood, 2015 }\end{array}$ \\
\hline Humans subordinate to & Criterion satisfied & Bunzel, 2015; LaPalm, 2014; \\
doctrine & & $\begin{array}{l}\text { McCants, 2015; Speckhard \& } \\
\text { Yayla, 2015 }\end{array}$ \\
\hline Dispensing of existence & Criterion satisfied & Alami, 2015; Barker, 2014; \\
Hoyle, Bradford, \& Frenett, \\
\end{tabular}

Table 4: Analysis of Lifton's criteria

The evidence reveals ISIS satisfies Lifton's criteria with one exception (i.e. confession). This outcome is consistent with LaPalm (2014). Since ISIS ideology is based on medieval Islam that did not recognize confession, this criterion does not apply. Lifton (1961, p. 435) contends " $t$ ] he more clearly an environment expresses these eight psychological themes, the greater its resemblance to ideological totalism ... No milieu ever achieves complete totalism." Therefore, this analysis supports the hypothesis.

The $\mathrm{ACH}$ is performed to ensure alternative hypotheses are adequately explored because of the importance of the final determination. The hypotheses tested are summarized in the methods section and the evidence (i.e., cult characteristics) selected for the analysis are summarized in Table 2

\begin{tabular}{|l|c|c|c|c|c|c|}
\hline Evidence & H1 & H2 $^{*}$ & H3 & H4 & H5 & H6 \\
\hline $\begin{array}{l}\text { Charismatic leader } \\
\text { living) }\end{array}$ & I & C & I & I & I & I \\
\hline $\begin{array}{l}\text { Authoritarian } \\
\text { leadership }\end{array}$ & I & C & I & I & I & I \\
\hline Exclusivism & I & C & C & I & I & I \\
\hline Nonconformists & I & C & C & I & I & I \\
\hline $\begin{array}{l}\text { Totalistic } \\
\text { organization }\end{array}$ & I & C & I & I & I & I \\
\hline $\begin{array}{l}\text { Systematic } \\
\text { indoctrination }\end{array}$ & I & C & I & I & I & I \\
\hline
\end{tabular}




\section{Journal of Terrorism Research}

\begin{tabular}{|l|c|c|c|c|c|c|}
\hline $\begin{array}{l}\text { Us-versus-them } \\
\text { mindset }\end{array}$ & I & C & I & I & I & I \\
\hline $\begin{array}{l}\text { Ends justify the } \\
\text { means }\end{array}$ & I & C & I & I & I & I \\
\hline $\begin{array}{l}\text { Aggressive } \\
\text { proselytizing }\end{array}$ & I & C & I & I & I & I \\
\hline Money driven & I & C & I & I & I & I \\
\hline
\end{tabular}

Legend: $\mathrm{C}=$ Consistent; $\mathrm{I}=$ Inconsistent

* See applicable references listed in Table 3 and Table 4

Table 5: Analysis of Competing Hypotheses

This analysis fails to identify any singular evidence that is consistent (C) or inconsistent (I) across all of the hypotheses. Conversely, evidence abounds that is inconsistent with the hypotheses that ISIS is not a religionbased organization (H1), ISIS is a sub-sect (H4), ISIS is a sect (H5), and ISIS is an accepted religion (H6). Of the two remaining hypotheses, the evidence is minimal for ISIS being a movement (H3) whereas the evidence is entirely consistent with ISIS being a cult (H2). Therefore, the ACH supports the hypothesis. The results of the analyses suggest ISIS falls far to the left on the Islamic typological continuum and supports the hypothesis ISIS is a cult. Although the analyses support the hypothesis rather than the null hypothesis, the terms apocalyptic and Islamic must still be explored.

\section{Discussion}

The assertion ISIS is an apocalyptic Islamic cult requires ISIS to satisfy each term (i.e. apocalyptic, Islamic, and cult). The word apocalyptic is defined as being concerned with the imminent end or radical transformation of the world (Berger, 2015, p. 61). There is little doubt ISIS is committed to returning to a seventh-century puritanical Islamic society whose ultimate goal is bringing about the apocalypse. Eschatology is an essential component of ISIS ideology, which is based on numerous apocalyptic references in the Islamic hadith (Socolovsky \& Winston, 2015).

There is some controversy regarding whether or not ISIS is truly Islamic (Cole, 2015; Volsky \& Jenkins, 2015). In fact, there are multiple arguments against ISIS practicing a true religion of Islam or being consistent with any mainstream Islamic sects, sub-sects, or movements. Schmid (2015, pp. 4) opines that "ISIS claims that it stands for pure and unadulterated Islam as practiced during the first three generations of successors of the Prophet. However, their claim is unsubstantiated and in the absence of theological proof." However, ISIS ideology is based on the Qur'an and hadith. Their organization, operations, and tactics are driven by these beliefs. Additionally, the aforementioned results demonstrate the link between ISIS and Islam. Indeed, if the religion of Islam, Islamic scriptures, and hadiths were removed from ISIS ideology, then it is highly unlikely this group would have ever emerged.

The analyses also strongly support the idea that ISIS is a cult. In particular, ISIS is trying to resurrect a medieval Islamic society under the rule of a caliph (Abu Bakr al-Baghdadi) whose word is unquestioned and final. Similar to other cults, ISIS has little tolerance for outsiders and believe they should be conquered, forced to convert, or killed. Not surprisingly, ISIS is in a high degree of tension with the dominant society 


\section{Journal of Terrorism Research}

as opposed to other religions and sects, a trait that is consistent with cultic behavior. Lastly, ISIS' long-term goal is "nothing short of world domination" (Friedland, 2015, p. 16). Unattainable goals, such as world domination, are also consistent with cultic mindsets.

The results of this study fail to support the null hypothesis that there is no relationship between ISIS and an apocalyptic Islamic cult; therefore, the null hypothesis is rejected and the hypothesis is accepted. More specifically, ISIS satisfies the criteria of an apocalyptic Islamic cult with a high degree of probability because ISIS meets the definition and criteria of a cult, meets the definition of apocalyptic, and maintains Islamic roots.

\section{Limitations}

Despite these outcomes, this study has several important limitations. First, there are no universally accepted definitions or criteria for terms such as cult and apocalyptic. Second, since quantitative statistics cannot be calculated, determining the degree of concordance between ISIS and other religious entities (e.g., Islamic movements and sub-sects) necessarily involves professional judgement. Third, determining the outcome of hypothesis testing through the application of Lifton's criteria also requires professional judgment because the number of criteria needed to define a cult was never established. Fourth, since most of the data are extracted from Western sources, there is the inherent risk of Western bias. Lastly, the circumscribed scope of this study is another limitation. Even though the analysis supports the hypothesis, the literature search yields other scholarly works suggesting ISIS is a sub-sect, sect, hybrid terrorist organization, guerilla army, revolutionary group, revolutionary state, and a pseudo-state.

\section{Areas for Future Research}

The research conducted in this study supports the assertion ISIS is first and foremost an apocalyptic Islamic cult. This observation offers some predictive value in developing counter measures to impede their current ability to survive and expand. Furthermore, the finding that ISIS is an apocalyptic cult has significant implications for U.S. policy and national security practitioners because the countermeasures needed to effectively neutralize this threat diverge from those used to defeat violent extremist groups. ISIS' multidimensional qualities can lead investigators to differing conclusions regarding the true nature of this organization. Therefore, further research is needed to asses these other dimensions and corroborate the primary outcome of this research: ISIS is a violent cult versus another type of organization. In addition, it will be important to assess the implications of this finding, especially with regard to how practitioners develop strategies to counter the group.

\section{Conclusion}

The results of this study support the hypothesis that ISIS is an apocalyptic Islamic cult. While there is little controversy regarding their apocalyptic nature, the literature lacks a consensus regarding their Islamic connection. To be sure there are experts who argue ISIS is not Islamic (Chapman, 2016; Unruh, 2016) and that its leaders are using religion to advance a political rather than a religious agenda (Hasan, 2015). While many Muslim scholars and clerics denounce ISIS, others argue that "when the ideologues of ISIS spell out in great detail their scriptures, tradition and history, they find the Islamic justification for what they are doing, it's simply nonsense to go on claiming that ISIS has nothing to do with Islam" (Chapman, 2016). This study 


\section{Journal of Terrorism Research}

found compelling evidence to support the argument ISIS ideology is based on Islam and the goal of ISIS is to recreate a medieval Islamic society. Indeed, it is highly unlikely ISIS would have emerged, endured, and expanded in the absence of its Islamic roots. This research also supports the claims of political figures and other key stakeholders that ISIS is a death cult. ISIS not only meets the definition of cult, this organization also manifests the characteristics of an apocalyptic cult.

\section{About the Authors}

Bruce A. Barron completed a Master of Science in Intelligence Management at Henley-Putnam University. His areas of interest and research focus on cults and violent extremist groups as it relates to strategic security. bruce_ barron@urmc.rochester.edu

Diane L. Maye is the Dean of Terrorism and Counterterrorism Studies at Henley-Putnam University. She completed a Ph.D. in Political Science from George Mason University with a focus on Iraqi politics. demaye@ henley-putnam.edu

\section{References}

ABC News. (2015, June 11). Islamic State: Tony Abbott's 'death cult' tag feeds terror group's propaganda machine, expert warns. Retrieved from ABC News: http://www.abc.net.au/news/2015-06-11/terrorismexpert-says-death-cult-is-a-isnomer/6539862

Al Arabiya. (2014, August 16). Philosophy and chemistry banned in schools by ISIS. Retrieved from Al Arabiya.com: http://english.alarabiya.net/en/perspective/features/2014/08/16/ISIS-calls-for-an-Islamiccurriculum-in-Syria-s-Raqa.html

Alami, M. (2015, May 6). The cult of ISIS and foreign recruits. Retrieved from Atlantic Council: http://www. atlanticcouncil.org/blogs/menasource/the-cult-of-isis-and-foreign-recruits

Alsodani, I. (2014). Islamic State organization, the rising, impact, and the degradation. Journal of International Affairs, 17(3), 5-8.

American Family Foundation. (2002, July 13). Cult 101: Checklist of cult characteristics. Retrieved from American Family Foundation: http://www.csj.org/infoserve cult101/checklists.htm

Barker, B. (2014). ISIS: Nothing new under the sun. Journal of Counterterrorism \& Homeland Security International, 20(4), 10-12.

Barron, B. (2015). Differentiating churches, sects, and cults: From the Church of England to Quakers and Shakers. (Unpublished manuscript). Department of Intelligence Management, Henley-Putnam University, Santa Clara.

Barron, B. (2016). Does the Islamic State of Iraq and al-Sham satisfy the criteria of an apocalyptic Islamic cult? (Unpublished master's thesis). Henley-Putnam University, Santa Clara.

Bean, D. (2016, February 17). How ISIS made Twitter one of its main recruiting tools-and what can be done about it. Retrieved from Independent Journal Review: http://www.ijreview.com/2015/08/380544-how-isismade-twitter-one-of-its-main-recruiting-tools-and-what-can-be-done-about-it/ 


\section{Journal of Terrorism Research}

Berger, J. (August 2015). The metronome of apocalyptic time: Social media as carrier wave for millenarian contagion. Perspectives on Terrorism, 9(4), 61-71.

Bunzel, C. (2015, March). From paper state to caliphate: The ideology of the Islamic State. Retrieved from The Brookings Project on U.S. Relations with the Islamic World: http://www.brookings.edu/ /media/research/ files/papers/2015/03/ideology-of-islamic-state-bunzel/the-ideology-of-the-islamic-state.pdf

Chapman, C. (2016, February 4). ISIS: Un-Islamic or true Islam? Retrieved from Zwermer Center: http:// www.zwemercenter.com/isis-un-islamic-or-true-islam/

Chulov, M. (2014, December 11). ISIS: The inside story. Retrieved from Guardian: http://www.the guardian. com/world/2014/dec/11/-sp-isis-the-inside-story

Cole, J. (2015, February 24). How 'Islamic' is the Islamic State. Retrieved from The Nation: http://www. thenation.com/article/how-islamic-islamic-state/

Cronin, A. (2015). ISIS is not a terrorist group. Foreign Affairs, 94(2), 87-98.

Cult Information Centre. (2016, February 28). What is a cult? Retrieved from Cult information.org: http:// cultinformation.org.uk/question what-is-a-cult.html

Dawson, L. (2006). Comprehending cults: The sociology of New Religious Movements. Ontario, Canada: Oxford University Press.

Deikman, A. (2003). Them and us: Cult thinking and the terrorist threat. Berkeley: Bay Tree Publishing.

Durden, T. (2016, January 22). Pentagon chief says 'boots on the ground' part of 'accelerated' strategy for ISIS fight. Retrieved from Ron Paul Institute: http://www.ronpaulinstitute.org/archives/featured-articles/2016/ january/22/pentagon-chief-says-boots-on-the-ground-part-of-accelerated-strategy-for-isis-fight/

Eckman, J. (2015, March 7). ISIS: An Islamic Armageddon. Issues in Perspective, 1-3.

Edwards, A. (2015). ISIS and the challenge of Islamist extremism. Political Insight, 12-15.

Essam, W. (2014, October 19). al-Baghdadi. Retrieved from al-Quds al-Arabia: http://www.alquds. co.uk/?p=237500

Festinger, L., Riecken, H., \& Schachter, S. (1964). When prophecy fails: A social and psychological study of a modern group that predicted the destruction of the world. London: Harper Row.

Friedland, E. (2015). Special report: The Islamic State. Washington, D.C.: The Clarion Project.Fromson, J., \& Simon, S. (2015). ISIS: The dubious paradise of apocalypse now. Survival Global Politics and Strategy, 57(3), 7-56.

Ganor, B. (2015). Four questions on ISIS: A 'trend' analysis of the Islamic State. Perspectives on Terrorism, 9(3), 56-64.

Giambalvo, C. (2008, February 17). What is a cult? Retrieved from Cult information and recovery: http:// members.aol.com/ ht a/carol2180/wcult.htm

Hasan, M. (2015, March 13). How Islamic is the Islamic State? Not at all. Retrieved from NewRepublic.com: https://newrepublic.com/ 


\section{Journal of Terrorism Research}

Herrmann, J. (2014, November 7). Internet brides of jihad: How Islamic State is using social media to lure young British women to Syria. Retrieved from Standard: http://www.standard.co.uk/lifestyle/london-life/ internet-brides-of-jihad-how-islamic-state-is-using-social-media-to-lure-young-british-women-to-9846143. $\underline{\mathrm{html}}$

Heuer, R., \& Pherson, R. (2011). Structured analytic techniques for intelligence analysis. Washington, D.C.: CQ Press.

Hoyle, C., Bradford, A., \& Frenett, R. (2015, January). Becoming Mulan? Female Western migrants to ISIS. Retrieved from Institute for Strategic Dialogue: http://www.strategicdialogue.org/ISDJ2969 Becoming Mulan 01.15 WEB.PDF

Inbari, P. (March 2015). The Islamic armageddon lies between Turkey and ISIS. Jerusalem Issue Brief, 15(6), $1-9$.

John, B. (2015, September 8). What is a cult? Retrieved from Theology of Mark T. Barclay: http:// theologyofmarktbarclay.com/author/bro-john/

Jones, M. (1998). The thinker's toolkit. New York: Three Rivers Press.

Kalyvas, S. (2015). Is ISIS a revolutionary group and if yes, what are the implications? Perspectives on Terrorism, 9(4), 42-47.

Lalich, J., \& Langone, M. (2015, December 13). Characteristics of cults. Retrieved from Apologetics Index.org: http://www.apologeticsindex.org/268-characteristics-of-cults

Langone, M. (2015). Characteristics associated with cultic groups-revised. International Cultic Studies Association Today, 6(3), 10.

LaPalm, M. (2014, October 28). Concerning features of an apocalyptic cult in the Islamic State of Iraq and the Levant (ISIL). Retrieved from Foreign Policy Journal: http://www.foreignpolicyjournal.com/2014/10/28/ concerning-features-of-an-apocalyptic-cult-in-the-islamic-state-of-iraq-and-the-levant-isil/

Lewis, R. (2015, March 6). ISIL's social media success from core group of Twitter users, studyfinds. Retrieved from Al Jazeera America: http://america.aljazeera.com/articles/2015/3/6/brookings-report-on-isils-twitter$\underline{\text { use.html }}$

Lifton, R. (1961). Thought reform and the psychology of totalism: A study of "brainwashing" in China. New York: W.W. Norton \& Company, Inc.

Lister, C. (2015, September 28). The West is walking into the abyss on Syria. Retrieved from Middle East Politics \& Policy: http://www.brookings.edu/blogs/markaz/posts/2015/09/28-west-walking-into-abyss-syria$\underline{\text { lister }}$

Masi, A. (2014, December 20). Westerners joining ISIS have tougher recruitment requirements to weed out ISIS spies. Retrieved from International Business Time: http://www.ibtimes.com/westerners-joining-isis-havetougher-recruitment-requirements-weed-out-isis-spies-1721314, accessed 20 December 2014.

McCants, W. (2015). The ISIS apocalypse: The history, strategy, and doomsday vision of the Islamic State. New York: St. Martin's Press.

Nelson, G. (1968). The concept of cult. The Sociological Review, 351-367.

Niebuhr, H. (1929). The social sources of denominationalism. New York: Holt Publishing.

Peresin, A. (2015). Fatal attraction: Western Muslims and ISIS. Perspectives on Terrorism, 9(3), 21-38. 


\section{Journal of Terrorism Research}

Pitts, B. (1998). Why Waco? Cults and the battle for religious freedom in America. Journal of Church and State, 209-210.

Rhodes, R. (2001). The challenge of the cults and new religions: The essential guide to their history, their doctrine, and our response. Grand Rapids: Zondervan.

Richardson, J. (1993). Definitions of cult: From sociological-technical to popular-negative. Review of Religious Research, 34(4), 348-356.

Schmid, A. (June 2015). Challenging the narrative of the "Islamic State". The Hague, Netherlands: International Centre for Counter-Terrorism.

Shubert, A., Haddad, M., \& Jones, B. (2016, January 24). Escaping ISIS: How French teen got free of terrorist recruiters. Retrieved from CNN: http://www.cnn.com/2016/01/19/europe/escaping-isis-paris-attackerradicalized-teen/

Socovsky, J., \& Winston, K. (2015, November 13). How ISIS is an apocalyptic cult, and what that means. Retrieved from The World Post-Religion News Service: http://www.huffingtonpost.com/entry/islamic-stateapocalyptic us 564e7d04e4b0d4093a5722aa

Souaiaia, A. (November 2015). The genealogy, ideology, and future of ISIL and its derivatives. Islamic Societies Review, 1-7.

Speckhard, A., \& Yayla, A. (2015). Eyewitness accounts from recent defectors from Islamic State: Why they joined, what they saw, why they quit. Perspectives on Terriorism, 9(6), 95-118.

Stark, R., \& Bainbridge, W. (1979). Of churches, sects, and cults: Preliminary concepts for a theory of religious movements. Journal for the Scientific Study of Religion, 18(20), 117-133.

Sun Tzu, t. b. (2000). The art of war. Retrieved from The Internet classics archive by Daniel C. Stevenson, Web Atomics: $\underline{\text { http://classics.mit.edu/Tzu/artwar.1b.txt }}$

Tilghman, A. (2016, January 14). This is the Pentagon's new strategy to defeat ISIS. Retrieved from Military Times: http://www.militarytimes.com/story/military/war-on-is/2016/01/14/pentagon-strategy-islamic-stateiraq-syria/78269180/

Tinaz, N. (2005). A social analysis of religious organizations: The cases of church, sect, denomination, cult and new religious movements (NRMs) and their typologies. Islam Arastirmalari Dergisis, 13, 63-108.

Troeltsch, E. (1931). The social teachings of the Christian churches. New York: Macmillan Publishing.

U.S. Department of Defense. (2015, December 15). Operation Inherent Resolve: Targeted operations against ISIL terrorists. Retrieved from U.S. Department of Defense: http://www.defense.gov/News/Special-

Reports/0814 Inherent-Resolve

Unruh, B. (2016, February 2). Iraqi columnist: ISIS terror is based on Islam. Retrieved from WND: http:// www.wnd.com/2016/02/iraqi-columnist-isis-terror-is-based-on-islam/

Volsky, I., \& Jenkins, J. (2015, September 11). Why ISIS is not, in fact, Islamic. Retrieved from Think Progress: http://thinkprogress.org/world/2014/09/11/3566181/why-isis-is-in-fact-not-islamic/

Walli, J. (2015). The psychology of detachment and hyperreality: Analysing ISIL's propaganda. Vaxjo, Sweden: Linnaeus University.

Walt, S. (2015). ISIS as revolutionary state. Foreign Affairs, 94(6), 42-51. 


\section{Journal of Terrorism Research}

Weber, M. (1964). The theory of social and economic organization. New York: Free Press.

West Point. (2007, January). A religious essay explaining the significance of the banner in Islam. Retrieved from Harmony Program, Combating Terrorism Center at West Point:https://www.ctc.usma.edu/posts/a-religiousessay-explaining-the-significance-of-the banner-in-islam-english-translation-2

Wood, G. (2015, March). What ISIS really wants. Retrieved from The Atlantic:http://www.theatlantic.com/ features/archive/2015/02/what-isis-really-wants/384980/

World News. (2015, November 22). World unites 'against ISIS death cult' in U.N. vote. Retrieved from World News: http://www.mojahedin.org/newsen/39625/World-unites-'against-ISIS-death-cult'-in-U.N.-vote Yinger, J. (1970). The scientific study of religion. Charlottsville, Virginia: Macmillan.

Zech, S., \& Kelly, Z. (2015). Off with their heads: The Islamic State and civilian beheadings. Journal of Terrorism Research, 6(2), 83-93. 